\title{
Enforcement of Intellectual Property Rights in Bangladesh: To What Extent Is It TRIPS-Responsive?
}

\author{
Mohammad Aktarul Alam Chowdhury \\ Department of Law, International Islamic University Chittagong (IIUC), Chittagong, Bangladesh \\ Email: aktarlawcu@gmail.com
}

How to cite this paper: Chowdhury, M. A. A. (2018). Enforcement of Intellectual Property Rights in Bangladesh: To What Extent Is It TRIPS-Responsive? Beijing Law Review, 9, 425-438. https://doi.org/10.4236/blr.2018.93026

Received: July 29, 2018

Accepted: September 15, 2018

Published: September 18, 2018

Copyright $\odot 2018$ by author and Scientific Research Publishing Inc. This work is licensed under the Creative Commons Attribution International License (CC BY 4.0).

http://creativecommons.org/licenses/by/4.0/

\section{c) (i) Open Access}

\begin{abstract}
In recent times with the adoption of TRIPS we observe that enforcement of Intellectual Property Rights (IPRs) has emerged as a pressing issue on the global economy, and in the national and international intellectual property agenda. Particularly, whilst the WTO definitely promotes big IP exporters, scholars are tremendously worried about TRIPS "one size fit all" attitude that ultimately disregards the heterogeneity of the world's populace and the exertions that threatens developing and least developed countries. The big and vital challenge facing by the developing country like Bangladesh today is how to cope with the mounting number of demands from intellectual property rights-holder, national and foreign, to upgrade their system for the enforcement of IPRs. And the effort of Bangladesh, in this respect, is not totally insignificant, for as a WTO family member Bangladesh imperatively needs to make it its IP regime TRIPS-responsive by 2021 starting from 1 July 2013. In this environment, this paper seeks to address briefly how the intellectual property rights are enforced in Bangladesh and to what extent the IPRs implementation and enforcement mechanism in Bangladesh is TRIPS-compliant. Finally this paper tries to put some recommendations to meet the WTO obligations using the TRIPS flexibilities.
\end{abstract}

\section{Keywords}

TRIPS, Intellectual Property, Flexibilities, Obligation and Enforcement

\section{Introduction}

The Agreement on Trade Related Aspect of Intellectual Property Rights (TRIPS) (Marrakesh Agreement, 1994) which was the successful result of the Uruguay 
Round in 1994, encompasses the very first sole agreement to deal with all main branches of intellectual property. In collaboration with World Intellectual Property (WIPO), it has meaningfully developed and harmonized an inclusive intellectual property regime (Maskus, 1993). Twenty years after the entry into force of the TRIPS agreement, strengthening enforcement of intellectual property rights (IPRS) has become a crucial issue in multiple international, regional and bilateral negotiations. In fact, over the past decade, the understanding on the relationship between intellectual property and development has increased significantly. Accordingly, it is more particularly significant today that developing and least developed countries maintain and avail the flexibilities that are available in the international IP instruments, rather than reinforce intellectual property protection without making a realistic evaluation of the needs, risks and impact of increasing protection.

However, from the very inception of the TRIPS, it becomes a touchy trade issue between developed, developing and least developed member states. Recently, after being the existence of TRIPS Agreement the member state experienced two fundamental approaches towards IP rights. Primary approach indicates that there has been a constant fight for stronger IP rights considering certain exaggerated estimates of the returns coming from such stronger regimes. Secondary approach, on the other hand, is concerned with a strong criticism of IP rights representing them as one of the strong impediments for industrialization of the developing and least developed countries (LDCs).

The arguments behind the first approach built on the belief that stronger IP rights would motivate and promote innovations with new technologies in the developed nations. Developing countries successively would be benefited by these innovations through foreign investment and technology transfer and hence accelerate their involvement in the world market and generate their development (Khan \& Azam, 2000).

Adversely, developing and LDCs are constantly feeling tension for reasons that such western-style IP regime does not cope with their customs and cultures and it exposes a homogenous and obligatory protection regime for all WTO members irrespective of developed, developing and LDCs. Particularly, whilst the WTO definitely promotes big IP exporters, scholars are extremely worried about TRIPS "one size fit all" attitude that ultimately disregards the heterogeneity of the world's populace and the exertions that threatens developing and least developed countries (Dreyfuss, 2009). These observations come into view as implications and hardships for developing and LDCs members in general in their IPRs-appropriating nature of developments needs in agriculture, access to affordable medicine, transfer of technology, economic development and so (UCTAD, LDC Report, 2007). In this context, Bangladesh, as an LDC faces such TRIPS implications and challenges since it depends mostly on agriculture for livelihood, generics of drugs for public health, transfer of technology and overseas patented commodities for reverse engineering for sustainable economic development. 
A robust safety measures for intellectual property right-holders is a factor in today's global economy to ensure that the technological advancement and economic development resulted out of the effort of creative people should be rewarded and valued. Unlike developed nation and multinational corporations developing and LDCs started to realize the necessity of intellectual property policy and laws as they have become the manufacturer and exporter of various IP products of different developed countries.

However, the big and vital challenges realized by the developing country like Bangladesh today is how to cope with the mounting number of demands from intellectual property rights-holder, national and foreign, to upgrade their system for the enforcement of IPRs. And the efforts of Bangladesh, in this respect, are not totally insignificant, for as a WTO family member Bangladesh imperatively needs to make it its IP regime TRIPS-responsive by 2013, that was later extended by the TRIPS council until 2021 as to the proposal pressed by the LDCs.

In order to exploit its potentials, especially in the field of science and technology Bangladesh has to frame modern IP policy and Laws using the utmost TRIPS flexibilities. In this environment, this paper seeks to address briefly how the IPRs are enforced in Bangladesh as a member of LDC status and to what extent the IPRs implementation and enforcement mechanism in Bangladesh is TRIPS-friendly. To this end this paper tries to put some recommendations to meet the WTO obligations using the TRIPS flexibilities.

\section{A Glimpse of TRIPS Agreement and Available Flexibilities}

The TRIPS Agreement is considered as the most comprehensive international intellectual property instrument concluded to date. For developing and LDCs the TRIPS Agreement meant that significant changes with the profound effects has to be introduced in their international systems to protect, promote and enforcement of IPRs.

On the basis of the previous conventions i.e. Paris, Bern, Rome and Washington conventions in their respective field, along with additional obligations, the TRIPS Agreements press some imperatives minimum standards for the strong safeguard and enforcement of IPRs (Peter, 2008). Adversely, this agreement does not represent an absolute self-governing convention, rather an integrative instrument which provides "convention plus protection" for IPRs (Peter, 2008). That's why the TRIPS agreement is labelled as the most striving international intellectual property convention ever attempted. According to the preamble, the TRIPS Agreement aims at "to reduce distortions and impediments to international trade.. taking into account the needs to promote effective and adequate protection of intellectual property rights." Although developing and least developed nations were able to introduce some public interest safeguards and flexibilities in the TRIPS agreement, the agreement is mainly deal with the granting and protection of the IP right-holders. In fact, the TRIPS is not merely about the protection measures of IPRs, rather it contemplates a balance between the pro- 
tection of IPRs and the transmission of knowledge in the developing countries to make sure of a abounded economy and technological development (Raj, 2008).

Some vital notion has been inserted in the Part-1 of the Agreement, for instance-the national treatment, most favoured-nations principles, exhaustion of rights, etc. which made an embargo in discrimination in the enjoyment of the IPRs on the basis of the country of origin. As per Article, 1 of the Agreement, every member state is allowed to find out the "appropriate method" to implement the agreement "within their own legal system and practice". Both the principle of "national treatment" and "most favoured nation" confers an obligation upon any member state to the agreement to ensure the same treatment to other nationals as provided for the nationals of the country where protection is granted and to extent, with some limited exceptions, to any member the advantages granted to any other member or members. In furtherance, Article 6 of the Agreement protects the consumer interests paving member states way to impart the "exhaustion of rights" and thus, to allow "parallel imports" if they are interested. The TRIPS Agreement also clearly emphasises under Article 7 that:

"The protection and enforcement of IPRs should contribute to the promotion of technological innovation and to the transfer and dissemination of technology, to the mutual advantage of producers and users of technological knowledge and in a manner conducive to social and economic welfare and to a balance of rights and obligations."

Moreover, in the Article 8 of the TRIPS further intended that-"WTO members may, when implementing TRIPS rules, adapt measures necessary to protect public health provided that such measures are consistent with the TRIPS Agreement." However, it is dependent on certain terms and condition as mentioned in Article 31 of the Agreement. Reaffirming their commitment to the TRIPS Agreement, members commended that the agreement can and should be interpreted and implemented in a manner supportive of WTO member's right to public health, particularly, to promote access to medicines for all (Para 4; TRIPS and Public Health, 2001). Therefore, "The agreement does not out line inclusive multilateral rules to make sure that national intellectual property regime performs in a manner that strikes an adequate balance between the interest of the right-holders and the public interest; rather the application of the flexibilities, limitations and safeguards contained in the TRIPS Agreement is left to national discretion (Tellez, 2009)."

Harmonizing with the WIPO convention, Part-3 of the TRIPS Agreement focuses on the enforcement mechanism of IPRs including the procedure for civil and criminal matter relating to copyright infringement and counterfeiting trademarks that likely to be happened at the point of importation. Indeed these rules set out to wield two objectives: firstly, to assure the IP right-holder that effective safeguard mechanisms are available; secondly, to confirm that enforcement procedure are regulated in such a way that sensibly would evade all sorts of possible barriers to lawful trade and uphold strong protection measures against their abuse (Haider, 2005). 
A thorough analysis of the TRIPS Agreement indeed reveals that the agreement leaves ample room for developing and LDCs to tailor their national intellectual property regime to ensure its enforcement in accordance with their economic and technological policies and their level of development. However, in practice, developing and least developed countries are often unable to do so due to the high transaction costs involved in complex and burdensome procedural requirements for implementing and enforcing appropriate legal provisions and for lack of technical knowledge or resources, as well.

\section{Present Intellectual Property Rights Enforcement Regime in Bangladesh}

Recently, Bangladesh, like other developing and least developed nations, keens to emphasis on FDI, transfer of technology and innovations with a view to smooth progress of economic development (Correa, 2007). Hence, it concentrates on trade liberalization by adapting and signing all the WTO Agreements including the TRIPS on 1 January 1995. Thus, TRIPS requires every member state, in addition to granting the right holders the minimum rights contained in the agreement, to established an effective national IP regime with a view to enforce their rights effectively (Haider, 2005). Realizing the practical significance of intellectual property the government of Bangladesh has taken some notable initiatives for the administration of the intellectual property complying with the TRIPS agreement. It has already enacted The Copyright Act, 2000 to meet the obligations set out in the TRIPS and has amended the said Act inserting the scope of computer program and enhancing the punishment and compensation for infringer of the computer program (Copyright Act, (Amended) 2005). Furthermore, Bangladesh government has also enacted new Trademark Act, 2009 and twisted the "Trademark Registry Wing" to deal the disputes concerned with trademarks owner and a certain level of intellectual property rights have been given to the trademark owners providing specific terms and conditions.

In addition to that, Bangladesh has framed the "Geographical Indication of Goods (Registration and Protection) Act, 2003" to protect certain typical goods popular in terms of their special nature, qualities or characteristics by geographical sign.

Patent protection is generally administered by the ancient Patents and Designs Acts of 1911, though amended several times, and the Patents and Designs Rules of 1933 (Khan, 2002). Being a least developed country, Bangladesh is free to comply with TRIPS to grant protection on pharmaceutical stuffs until 2016 which is extended now until 2033 (The World Bank, March 2008). As per the provisions of old patent law of the country patent rights are protected for a total of sixteen years counting from the date of filling of patent application and it can be extended further for ten years (Patent \& Design Act 1911).

Recently the government has merged the Patent Office and the Trademarks Registry Office and formed a new department named "Department of Patents, Designs and Trademarks" (DPDT), regulated under the Ministry of Industries. 
An aggrieved person can file an appeal before the High Court Division against the decision of the registrar (Rahman, 2011). Owners of intellectual property in Bangladesh can also file a written petition to the Registrar of the copyright office to ban immediately the importation of infringed good into Bangladesh (WTO Trade Policy Review Body, 2006).

In spite of updating some IP laws providing stronger IPRs protection and enforcement mechanism, Bangladesh is still facing different types of complexities to enforce the same in practice. Bangladesh. like other LDCs, is to make its intellectual property regime TRIPS-biddable within 2013, that was later extended by the TRIPS council until 2021 as to the proposal pressed by the LDCs. Bangladesh is required to explain WTO about the current position of national IP laws and its effective enforcement system.

\subsection{Enforcement System under the Trademark Act, 2009}

To date, Bangladesh has made a very significant progress to change its intellectual property rights specially concerned with the trademarks under the Trademarks Act 2009 in line with the obligation set out in the TRIPS Agreement. And at the same time it has introduced manifold civil and criminal remedies like penalty and compensations for the infringement of right of a trademark-holder. In pursuance of section 96 of Trademarks Act, 2009-"anybody can bring the matter to the court not inferior to a court of District Judge in case 1) any registered trademark is infringed; 2) it involves any right or amended right related to the registered trademark; and 3) any similar or deceptively similar trademark whether it is registered or not." Accordingly the court is empowered to provide remedies like injunction, compensation or part of profits to right-holder. The court also may give an order to damage, wife out or remove the level or marks (Section 97, Trade Mark Act, 2009). It is to be noted that the Act has also expanded the meaning and scope of trademark violation inserting a number of circumstances. As per the criminal remedies the Trademark Act 2009 also ensures different terms of punishment including imprisonment and imposition of fine or both for the infringer of other's mark or indication relating to the goods or services and seizure of infringing goods, products or copies.

\subsection{Enforcement System under the Copyrights Act, 2000}

To set in line with the obligation of TRIPS the updated Copyrights Act 2000 has put stronger enforcement mechanism in place. According to the provision 71 of the Act:

"a person is considered to be infringed copyright if that person 1) sale or hires; or causes to sale or hire; or exhibits commercially; or proposes to sale or hire the infringing copies of the work; 2) distributes either for the purpose of trade or to such an extend as to affect prejudicially the owner of copyright, any infringing copies of the work; 3) exhibits commercially in public the infringing copies; 4) import any infringing copy into Bangladesh (Section 71, Copyright 
Act 2000)." The owner of copyright can bring an action in the court of district judge within his jurisdiction against any person who infringed his copyright, seeking injunction, compensation or search warrant or accounts. Besides, if there is any apprehension that the infringer would demolish the proof of infringement with a view to defeat the justice, in that case the court has the option to apply Anthon Pillar Order ${ }^{1}$ or search order as an instrument to help the copyright holder (Azam, 2008).

As to the Criminal remedies if any person infringed the right without authorisation of the copyright owner s/he will be liable to be punished with imprisonment for a period of 6 months to 4 years and fine which may be around 50 thousand to 2 lakh. It is to be mentioned here that in case piracy of computer program the present copy right Act expand the amount of fine by an amendment on May 18, 2005. In a criminal case police is empowered to investigate the case and to conduct raids to seize counterfeit and pirated goods coordinating with Customs authority.

\subsection{Enforcement System under the Patents and Designs Act, 1911}

As mentioned earlier, in Bangladesh protection and enforcement of the rights of the patentee is governed by the rules and procedures provided in the former $\mathrm{Pa}$ tents and Designs Acts of 1911. Government may revoke any paten application if it is not used reasonably, not utilized within reasonable time or on any other public ground or national interest etc. In addition, as a signatory state of a Paris Convention and the WTO treaties, particularly, on patents and designs, Bangladesh has an obligation to frame an uniform laws on intellectual property including patents and designs.

According to this old law an owner of patent may invoke the jurisdiction of District Judges Court against the person who infringed the patentee's rights by selling, making or using the invention without his authorisation or license or counterfeit it, or imitates it. As per section 29 of the Act "in case of counter claim is submitted by the defendant for the revocation of the patent, the court transfer the suit to the High Court Division along with the counter claim, recording the reasons thereof." In a patent infringement suit, the court may issue an order of injunction, inspection, of account on application of either party, or impose such terms and give such directions, as the court may deem fit (Section 31, Patent \& Designs Act 2011).

\section{Enforcement of IPRs in Bangladesh: How Far Bangladesh Progressed as to the TRIPS Requirements?}

As a WTO family member Bangladesh imperatively needs to make it its IP regime TRIPS-responsive by 2013, that was later extended by the TRIPS council until 2021 as to the proposal pressed by the LDCs. LDCs are given such an ex${ }^{1}$ Under the Anthon Pillar Order plaintiff can approach court in camera to issue search order without giving any notice to the defendant to enable the plaintiff to search defendant's premises or infringing copies. 
tended transition period to enforce and protect intellectual property rights under the WTO's Agreement TRIPS, so that they can create a sound and viable technological base. The TRIPS Agreement's preamble already acknowledged LDCs' particular need for maximum flexibility in implementing laws and regulations domestically. In order to exploit its potentials, especially in the field of science and technology Bangladesh has to frame modern IP policy and Laws using the utmost TRIPS flexibilities. It has been widely recognized that Bangladesh Government has taken a series of initiatives aiming at the strong safeguard measures and effective enforcement of intellectual property rights in line with the requirements incorporated in the TRIPS Agreement.

First and prime achievement of Bangladesh is the enactment of the Copyrights Act, 2000 which is considered one step ahead to comply with the obligation under TRIPS agreement. And this Act has been amended in 2005 with a view to expand the range of computer programs and to increase the punishment and fine for the violation of copyright in computer programs. Despite the fact that new copyrights law Bangladesh has twisted an updated protection regime the Copyrights Act 2000 looks like to be prehistoric. Because the act does not provide any strong safeguard mechanism against online copyrights piracy, meta-tagging or $\mathrm{p}-2$-p broadcast of copyrights substances, copyrights in database and restrictions in deep linking (Islam, 2016). Besides the new Copyright law is very silent about equitable royalty of the stakeholders in the music industry.

Secondly, the government of Bangladesh has enacted the Trademarks Act, 2009 in proportion to the obligation intended in the TRIPS Agreement referring multiple remedies, penalty and compensations through civil and criminal proceedings for the intentional violation of the right of a trademark-holder.

Thirdly, as to the provision concerned "any manner of new manufacture including an improvement thereof" the present Patents and Designs Act, 1911 seems to be incorporated a liberal and wide slant of patentability criteria in Bangladesh. However, plant varieties of farmers are not covered under the patent protection in Bangladesh because they are not conjunction with the criteria of "novelty" and putted in the public domain. Further, under the present Patent Act, inventor of a design is not able to claim any right qua design on his invention let alone copyrights on designs. Additionally, the old Act is totally silent about the protection of "petty patents" or "utility models" that can encourage the small entrepreneurs or individuals to contribute the socio-economy. However, recently special transition period for pharmaceuticals of Bangladesh is further extended until 2033, starting from 1 January 2016 to formulate its patents regime into TRIPS compliant. To this context all such applications for the grant of patent protection on the pharmaceutical product of Bangladesh will be stored in a "mailbox" (Khan, 2009) until 2033. Bangladesh is obliged to implement the "mailbox" provision for the protection of pharmaceutical patents (Van Duzer, 2003).

Fourthly, as a part of obligation to formulate TRIPS responsive IP law, Bangladesh is now working with the EU based on a bilateral treaty which requires 
revising its IP Law compatible with the TRIPS Agreement (Sampath, 2007). To this end, the Patents and Designs office has prepared a new draft law called Patents and Design Act 2006, with the help of the World Intellectual Property Organisation (WIPO). This new draft law excludes pharmaceutical products from patent protection as to the TRIPS flexibility until 2033 and introduces the "Bolar provision" and regulations on "parallel importation" (Article 6, TRIPs Agreement). However, in line with Article 33 of TRIPS Agreement, new drafts law on patents grants 20 years patent protection to the patentee from the filling date of the patent petition (The World Bank, March 2008).

Fifthly, merging the Patents Office and Trademarks Registry Office though government has set up (DPDT), lack of coordination among the patent and copyrights office and expertise on cross-cutting issues are still remain as a big challenge to ensure a IPRs friendly environment within the country.

Sixthly, as to the obligation of Patent Cooperation Treaty (PCT), Patent Unite of the country is undergoing a project to simplify the procedure of filling of patent application by introducing computer automation.

Seventhly, the Drug Directorate Administration (DDA) of Bangladesh is responsible for providing accurate and relevant product information regarding quality, safety and efficiency of medical devices in Bangladesh.

Eighthly, as regards the protection of trade secrets the country has no specific law till date except the general provisions of Competition Act 2012 and the Contract Act 1872 . The country also needs to make a law providing strong protection mechanism to prevent unfair competition and to protect layout design and integrated circuits as well.

Finally, in respect of Geographical Indication (GI) Bangladesh government has enacted "the Geographical Indication of Goods (Registration and Protection) Act, 2013". But in practice the definition of genericide in the said Act is very extensive that put the Bangladeshi GIs into susceptible to genericide as it become generic very easily. The country also enacted the Information and Communication Technology law in 2006 to prevent software piracy (Hoque, 2010). Therefore, all the IP policies and initiatives so far have been adopted by Bangladesh as a WTO member state, are considered as a good sign to make its IP regime TRIPS compliant by 2021.

However, some researchers and legal experts observe that a number of loopholes and difficulties are still prevailing in the effective intellectual property enforcement mechanism in Bangladesh. For instances, most of the procedural laws currently enforceable in Bangladesh, are seemed to be very age-old in terms of defining and protecting IPRs, covering emerging issues in IPRs, identifying causes of infringement of IPRs in a globalized world and promoting suitable development (Islam, 2007). Those laws have not been updated to address the much nuanced problems of multiple types of intellectual properties in Bangladesh and ${ }^{2}$ The "Bolar" provision permits use of patented medicines for experimental purposes before the patents expired and it is very important for reverse engineering of medicines.

${ }^{3}$ Parallel importation happens when the importer of a drug from another country does not need to pay a royalty as the exporter has already paid it. See Article 6 of TRIPS Agreement. 
are not suited with the socio-economic conditions prevailing in the country.

The draft patent law does not exploit TRIPS flexibilities properly and it also disappointed to focus public health issue and other related issues in right direction.

In this respect Professor Mr. M Azam rightly pressed that "there is no innovative approach in law making considering our stage of development, national interest and socio-economic conditions rather than traditional approach and blindly followed the footstep of some neighbouring countries without critical evaluation of our national interest" (Azam, 2008). At the same time this draft is very silent about the concept of utility model though WIPO experts commented that the concept of utility model certificate can be integrated in the Patents and Designs Act, (Report on Bangladesh \& WIPO Expert's Discussion, 2000).

It is also to be mentioned here that Bangladesh has no specific laws till date regarding protection of Plant Variety, Traditional Knowledge, Layout designs of Integrated Circuits. Consequently, legal protection of those IP related rights are not possible at national or international level as those IP rights are not recognised under the exiting Intellectual Property Laws.

Moreover, though Information and Communication Technology law has been enacted in 2006 to prevent software piracy, there is an absence of specialized enforcement agency or custom officials to conduct the alleged investigation of infringement with adequate and modern technological knowledge and expertise. As a result the existing enforcement mechanism remains fruitless and ineffective.

On the other hand, delay in disposal of the civil and criminal matter and high litigation cost are also liable to lose the faith of affected people in judiciary to take resort to the court for effective remedy. In addition, lack of strong infrastructures and sufficient resources, both technical and financial, are also responsible for lack of effective IPRs enforcement system within the country, causing the downtrend of country's economy and development.

It is also admitted that there is no study as to how modern IP policy and law boost the socio-economic development along with the scientific and technological advancement giving policy priority. In fact, an effective and strong intellectual property regime depends on policy oriented and proper legal framework, consistent with IP-friendly judicial activism (Azam \& Chowdhury, 2008).

\section{Way Forwards to Ensure a TRIPS-Responsive IP Regime in Bangladesh}

In reality, it is a very daunting task for Bangladesh and has to face formidable challenges to make its IP regime fully TRIPS compliant by 2021 . However, from the view point of above discussion it is recommended to take following Bangladesh strategy and policy frameworks to boost the IPRs enforcement mechanism in Bangladesh that would help to make the IP regime TRIPS-compliant:

1) In order to enjoy the WTO membership Bangladesh has to formulate im- 
mediately a comprehensive and modern legal framework updating it's the long-standing colonial laws, in particular patent, designs, geographical indication, and utility model laws etc. immediately. In this regards policy makers can utilize Article 1, $7 \& 8$ of TRIPS Agreement that reefers TRIPS flexibilities to enforce the interest of IP right holder and the common people at large.

2) Strong governmental support is needed, like in India and China, for maintaining an effective structure of laws and enforcement procedures towards successful implementation compatible with those of developed countries and encouraging domestic innovations. For instances, tax incentives, encouraging foreign direct investment, and setting up strong infrastructure supportive to research and innovation etc.

3) Policy assistance should focus initially on framing or modifying such IP laws that will protect the national interest on the one hand and pave the way to exploit its potentialities in the field of science and technology on the other, provided it helps to fulfil WTO obligations. At the national level, domestic policy maker should along with formulation of proportioned legal principles, aim for educating public as regards the cost of blatant disregard of IP rights. Thus with the knowledge based leadership all sorts of possible obstacles and complications in the enforcement mechanism of IP rights can be got round. In this context, Government can take initiatives for the awareness campaign among the people about the significance and effective enforcement of IPRs.

4) With a view to deal with the challenges that may be posed by post-TRIPS regime, technical assistance and capacity building within the regulatory agencies and other services is a must to promote the development in scientific and technological area.

5) Regarding regulatory framework, Bangladesh has to determine strategy and policies and equipped government institutions and officials to fight against IPRs infringement effectively. Policy should include the technical assistance of necessary training for the officials of both government and firms.

6) In order to successful implementation of the reform agenda, policy should also comprise technical and financial support aiming at increasing capacity building of the regional IP offices, governmental institutions and officials ensuring transparency and accountability. In this respect, Government, as to the Article 67 of TRIPS Agreement, can seek cooperation from WIPO, WTO and the developed countries to provide technical and financial assistance to make a comprehensive and effective IP regime complying with TRIPS requirements

7) Bangladesh must establish specialized IP courts or tribunals with trained judges, who are acquainted with updated IP laws, multiple complicated IP issues and their safeguard procedure, for suitable, satisfactory and early disposal of dispute related with the Intellectual Property rights.

8) Lastly, considering the socio-economic interests of the country, an integrated approach is needed to create a national governing body for intellectual property consists of the members from Apex court, IP specialists, lawyers, university teachers, and business community to deal with the IP issues more effec- 
tively and to strengthen the performance of the IP sector of the country.

\section{Concluding Remarks}

In today's global economy the enforcement of intellectual property rights has initiated huge questions and controversy. Analysing various studies, however, some scholars argued that strong protection mechanisms of IPRs in developing and least developed countries can boost their scientific innovations and technological advancement that will consequently enrich economic growth and eradicate poverty in the country (Vincent, 2009). Thus protection and enforcement mechanism of IP rights may become a tool for developing and least developed countries to enhance economic and technological growth provided that the country has ability to grasp and utilize modern technology.

In spite of strong criticism against TRIPS and having a considerable debate between developed and developing states, Bangladesh should persist on strengthening capacity building and coordination among different governmental institutions and bodies concerning intellectual property issues at the national, regional and international level. Such kind of constant coordination and contact would certainly pave the way for the maximum utilization of various TRIPS flexibilities and facilitate in the implementation process of TRIPS effectively and meaningfully.

To overcome the challenges described in this paper for ensuring compliance with the TRIPS obligation in the national legal system, government also needs to work with the other WTO member states combined with political commitment which makes IP regime in Bangladesh more thriving and prospective. Because an effective IP regime may be a factor in attracting FDI which in all likelihood is a non-decisive factor and more importantly, if IP rights prevailing among developing and least developed countries are further harmonized by international legal instruments, IP rights would be even less germane to FDI decisions (Correa, 2000). Hence, the ideal legal regimes in domestic level perhaps that one which can strike a balance between rival legal interests and formulate principles those would not heavily favour any particular group.

The Commission on Intellectual Property Rights of UK rightly concluded that "the interest of developing and least developing countries would best be served if their policy maker can design their IP right regime in a way that suits their particular economic and social circumstances (UK Commission Report, 2000).”

Though Bangladesh has already taken multiple steps to update its domestic IP regime compatible with TRIPS agreement by enacting new Trademarks, Copyrights and geographical indication laws and taken initiatives to make new laws on patents and designs, utility model etc. and established DPDT, these masseurs are not well enough if we analyse and compare with them with the IP regime and policy of some other developing nations like India, Brazil, Indonesia etc.

However, it is widely admitted that taking into account the national reality and its commitment towards WTO, Bangladesh should make efforts to attain 
maximum level of skill and knowledge to exploit the TRIPS flexibilities. To achieve this target, emphasis must be placed not only on framing intellectual property laws, but also ensuring that those laws are effectively enforced. In sum, policy priority, IP-friendly judicial activism, pro-active investigating agency i.e. police and custom and political commitment will be sine qua non for ensuring a strong and sustainable enforcement mechanism of IPRs.

\section{Conflicts of Interest}

The authors declare no conflicts of interest regarding the publication of this paper.

\section{References}

(2000). Report on Discussion between Bangladesh Delegation and WIPO Experts on Proposed Patents and Designs Act, Trademarks and Merchandise Marks Act, Copyrights Act 2000 and Other Subject of Intellectual Property Rights.

(2000). UK Commission Report on Intellectual Property Rights: Integrating Intellectual Property Rights and Development Policy, London.

Azam, M. M. (2008). Intellectual Property, WTO, and Bangladesh. Dhaka: New Warsi Book Corporation.

Azam, M. M., \& Chowdhury, A. H. (2008). IP Enforcement Mechanisms to Combat Piracy: The Context of Software Piracy. Asian Journal of International Law, 3, 117-118.

Copyright (Amended) Act, (2005), Act No. 28 of July 18, 2000.

Correa, C. M. (2000). Intellectual Property Rights, The WTO and Developing Countries: The TRIPS Agreement and Policy Option for Developing Countries. New York: Zed Books.

Correa, C. M. (2007). Intellectual Property Rights, the WTO and Developing Countries: The TRIPS Agreement and the Policy Option (pp. 23-24). Oxford: Oxford University Press.

Dreyfuss, R. C. (2009). TRIPS and Essential Medicine; Must One Size Fit All? Making the WTO Responsive to the Global Health Issue. Public Law and Legal Theory Research Paper Series No. 09-44, New York University School of Law, 52-86.

Haider, N. (2005). Enforcement of Intellectual Property Rights from the Perspective of TRIPS Agreement. Dhaka University Studies Part-F. Journal of the Faculty of Law, 16, $32-48$.

Hoque, M. E. (2010). Milestone of Intellectual Property Rights Administration in Bangladesh. A Souvenir Published by the DPDT, Dhaka, 19-21.

Islam, M. T. (2007) The TRIPS Agreement in Bangladesh: Implications and Challenges. Dhaka University Law Journal, 8, 67.

Islam, M. T. (2016) TRIPS Agreement And Bangladesh, in The Daily Star, February 2, 2016, Dhaka. http://www.thedailystar.net/law-our-rights/story.php?nid=27621

Khan, A. A. (2002). The Law of the Trade Marks Copyrights, Patents and Designs. Dhaka: New Warsi Book.

Khan, J. U. (2009). New Patent Right of Drug Suspended. The Daily Star, 14 March 2008. Dhaka, Bangladesh.

http://www.thedailystar.net/story.php?nid=27621

Khan, M. M., \& Azam, M. (2000). TRIPS Agreement and Protection of National Interest: 
Contention between Developed and Developing Countries. The Chittagong University Journal of Law, 5, 1-34.

Marrakesh Agreement (1994). Establishing the World Trade Organisation, Opened for Signature $15^{\text {th }}$ April 1994, 1867 UNTS 3, Annex 1C, Entered into Force $1^{\text {st }}$ January 1995. [Hereinafter the TRIPS Agreement]

Maskus, K. E. (1993). Trade Related Intellectual Property Rights. European Economy, 52, 157-184.

Patent \& Design Act 1911.

Peter, B. V. D. (2008). The Law and Policy of the World Trade Organisation: Text Case and Materials (pp. 741-750). Cambridge: Cambridge University Press.

Rahman, M. M. (2011). Intellectual Property Protection in Bangladesh: An Overview. http://www.unescap.org/tid/mtg/ip_bang.pdf

Raj, B. (2008). International Trade Law: Interdisciplinary Theory and Practice (pp. 16-23). Newark, NJ: LexisNexis.

Sampath, P. G. (2007). Innovation and Competitive Capacity of Bangladesh Pharmaceutical Sector (p. 15). UNI-MERIT Working Paper Series 2007-31.

Tellez, V. M. (2009). The Changing Global Governance of Intellectual Property Enforcement: A New Challenges for Developing Countries in Intellectual Property Enforcement, International Perspectives (p. 8).

The World Bank (2008). Public and Private Sector Approaches to Improving Pharmaceutical Quality in Bangladesh. Bangladesh Development Series, Paper No. 23, Human Development Unit South Asia Region.

TRIPS Agreement and Public Health (2001). Paragraph 4 of the Declaration on the WTO Document WT/MIN (01)/DEC/2 of the 20 November 2001.

UCTAD Report (2007). United Nation Conference on Trade and Development, Least Development Countries Report 2007; Knowledge Technological Learning and Innovation for Development, Geneva (pp. 125-126).

Van Duzer, T. (2003) TRIPS and Pharmaceutical Industries in Bangladesh: Towards a National Strategy. CPD Occasional Paper Series No. 24.

Vincent, S. W. (2009). The Economic Arguments for a Patent System: A Modern Development Perspective. Quarterly Economic Viewpoint Publication, No. 3.

WTO (2006). Trade Policy Review Body, WT/TPR/M/168/Add.1. 